\title{
SEQUENCE POLYMORPHISMS OF FOUR CHLOROPLAST GENES IN FOUR ACACIA SPECIES
}

\author{
Anthonius Y.P.B.C. Widyatmoko ${ }^{1,2}$ and Susumu Shiraishi ${ }^{3}$
}

\begin{abstract}
Sequence polymorphisms among and within four Acacia species, $A$. aulacocarpa, $A$. auriculiformis, $A$. crassicarpa, and $A$. mangium, were investigated using four chloroplast DNA genes (atp $\mathrm{A}$, pet $\mathrm{A}, r b c \mathrm{~L}$, and $r p o \mathrm{~A})$. The phylogenetic relationship among these species is discussed in light of the results of the sequence information. No intraspecific sequence variation was found in the four genes of the four species, and a conservative rate of mutation of the chloroplast DNA genes was also confirmed in the Acacia species. In the atp $\mathrm{A}$ and $p e t \mathrm{~A}$ of the four genes, all four species possessed identical sequences, and no sequence variation was found among the four Acacia species. In the $r b c \mathrm{~L}$ and $r p o \mathrm{~A}$ genes, however, sequence polymorphisms were revealed among these species. Acacia aulacocarpa and $A$. crassicarpa shared an identical sequence, and $A$. auriculiformis and $A$. mangium also showed no sequence variation. The fact that $A$. mangium and $A$. auriculiformis shared identical sequences as $\operatorname{did} A$. aulacocarpa and $A$. crassicarpa indicated that the two respective species were extremely closely related. Although a putative natural hybrid of $A$. aulacocarpa and $A$. auriculiformis has been reported, our results suggested that natural hybridization should be further verified using molecular markers.
\end{abstract}

Keywords: Acacia, sequencing, chloroplast DNA, phylogeny

\section{INRODUCTION}

There are more than one thousand documented species of Acacia, of which about 650 species occur in Australia. Acacia auriculiformis, A. mangium, A. aulacocarpa, and $A$. crassicarpa are four of only nine Australian Acacia species, whose distributions extend northward into Papua New Guinea and Indonesia (Moran et al., 1989). The four species are multiple-purpose plantation species, and in the last decade, they have become a major plantation species used for pulp production in Southeast Asia. Acacia species have been introduced in commercial plantations in Southeast Asia. The total area of tree plantations is now approaching two million ha and the largest of these plantations (about 1.2 million ha) is located in Indonesia, where the major planted species is fastgrowing Acacia mangium Wild. (Arisman and Hardiyanto, 2006; Potter et al., 2006). In industrial pulpwood plantations, these four Acacia species are newcomers compared

\footnotetext{
${ }^{1}$ Center for Forest Biotechnology and Tree Improvement Research, Jl. Palagan Tentara Pelajar Km. 15, Purwobinangun, Pakem, Sleman, Yogyakarta, Indonesia.

2 Corresponding Author. E-mail: aviwicaksono@yahoo.com

${ }^{3}$ Laboratory of Silviculture, Faculty of Agriculture, Kyushu University, Fukuoka, Japan
} 
to Eucalyptus. However, these species are suitable for kraft pulp production based on criteria such as basic density, bleaching properties, and pulp quality.

The genetic relationship among the four species is important for evolutionary study. In breeding programs, this information is useful for predicting hybridization activities. Until now there has been little discussion of the relationship among these species (Pettigrew and Watson, 1975; Boland et al., 1990; Brain and Maslin, 1996). Moreover, the classification of the four species is not well elucidated. Some studies have been conducted in order to investigate the relationship among the four species (Widyatmoko et al., 2010); however, no phylogenetic analysis among the four species has been reported using the sequence information of chloroplast DNA (cpDNA) genes. Phylogenetic relationship among Acacia species have been reported by Clarke et al. (2000), Byrne et al. $(2001 ; 2002)$ and Brown et al. (2008). Both of the research were using chloroplast DNA. Acacia species which have been used for phylogenetic relationship study revealed the significant association between phylogenetic position of many haplotypes and their geographical distribution. Hamrick et al. (1992) reported the effect of pollination to genetic diversity of species. Long-lived, outcrossing and wind-pollinated species has higher levels of allozyme diversity within population and less among population.

DNA sequences of cpDNA genes have been utilized for estimating the phylogeny of many taxa of plants. In particular, the chloroplast gene $(r b c \mathrm{~L})$ that encodes a large subunit of the enzyme ribulose-1,5-biphosphate carboxilase has been used to elucidate the relationships of Betulaceae (Chen et al., 1999), Rutaceae (Chase et al., 1999), Salix (Azuma et al., 2000) and Solanum (Bohs, 2004). Intraspecific sequence polymorphism of cpDNA has also been investigated (Fujii et al., 1999; Amane et al., 2000; Zimmer et al., 2002).

In this study, sequence polymorphisms among the four Acacia species were investigated using four cpDNA genes (atpA, pet $\mathrm{A}, r b c \mathrm{~L}$, and $r p o \mathrm{~A})$. Furthermore, a phylogenetic relationship among these species was discovered and is discussed with the results of the sequence polymorphism.

\section{MATERIALS AND METHODS}

Plant materials for the study were obtained from the Australian Tree Seed Centre of CSIRO (Commonwealth Scientific and Industrial Research Organization), Australia, and from the Forest Tree Improvement Research and Development Institute, Indonesia. For each species, four seedlots (represented by one seed) were used for sequencing. Details of each sample are shown in Table 1.

Total genomic DNA was extracted from the seeds with a mortar and pestle by an SDS isolation. Each seed was ground using $400 \mu \mathrm{l}$ SDS extraction buffer, which contained $50 \mathrm{mM}$ Tris-HCl (pH 9.0), 1\% (w/v) SDS, $10 \mathrm{mM} \mathrm{EDTA,} \mathrm{and} \mathrm{0.5 \%} \mathrm{(v/v)}$ 2-Mercaptoethanol. After incubation at $65^{\circ} \mathrm{C}$ for $60 \mathrm{~min}, 200 \mu \mathrm{l}$ of $7.5 \mathrm{M}$ ammonium 
acetate was added. The solution was kept on ice for $30 \mathrm{~min}$, and was then centrifuged at $0^{\circ} \mathrm{C}$ at 15,000 rpm for $40 \mathrm{~min}$. The sample in the aqueous phase ( $\left.400 \mu \mathrm{l}\right)$, was transferred to a new tube, and the DNA was precipitated by the addition of $400 \mu \mathrm{l}$ isopropanol. After circa $10 \mathrm{~min}$, the precipitate was collected by centrifugation at 15,000 rpm for 10 min. The supernatant was completely removed, and the pellet was washed twice with 1.0 $\mathrm{ml}$ of $70 \%$ Ethanol. After the pellet was washed using a vacuum evaporator for $2 \mathrm{~min}$, it was resuspended in $100 \mu \mathrm{l}$ purified $\mathrm{H}_{2} \mathrm{O}$. Finally, the crude solution was purified using a GeneClean III Kit (BIO 101), and the purified DNA was utilized as a template for PCR.

Table 1. List of sample materials for the four cpDNA genes

\begin{tabular}{|c|c|c|}
\hline \multirow[t]{2}{*}{ Species } & \multicolumn{2}{|c|}{ Seed source } \\
\hline & Seedlot No. & Location* $^{*}$ \\
\hline \multirow[t]{4}{*}{ A. aulacocarpa } & $16946-\mathrm{AK} 000012^{* *}$ & Balimo District, PNG \\
\hline & 13866-BH $012313^{* *}$ & Garioch, QLD \\
\hline & 17905-TREE** & 10K NW Mt. Molloy, QLD \\
\hline & 17739-BG 000022** & 3K S Mt. Larcom, QLD \\
\hline \multirow[t]{4}{*}{ A. auriculiformis } & 16606-BVG 01220** & Morehead R Rouku WP, PNG \\
\hline & 18359-MHL 20** & Lower Poscoe River, QLD \\
\hline & $16756-B G 004936^{* *}$ & E Normamby River, QLD \\
\hline & $18601-6^{* *}$ & (R) Orchard Melville Is., NT \\
\hline \multirow[t]{4}{*}{ A. crassicarpa } & AC-1107** & Kuel, Irian Jaya, IND \\
\hline & 13680-JC 001503** & Wemenever Prov., PNG \\
\hline & 17944-MHL 04** & Claudie River, QLD \\
\hline & 16775-ВН $013582^{* *}$ & Parish of Annan, QLD \\
\hline \multirow[t]{4}{*}{ A. mangium } & $570^{* * *}$ & Piru, Seram, IND \\
\hline & 16971-BVG 01626** & Wipim District WP, PNG \\
\hline & 17946-GJM 1110** & Claudie River, QLD \\
\hline & 17703-GLM 00920** & Tully-Mission Beach, QLD \\
\hline
\end{tabular}

Notes: * PNG, Papua New Guinea; QLD, Queensland, Australia; NT, Northern Territory, Australia; IND, Indonesia

** Seedlot No. of CSIRO, Australia

*** Seedlot No. of FTIRDI, Indonesia

Seven pairs of PCR primers shown in Table 2 (Shiraishi et al., unpublished) were used for amplifying four genes. PCR was performed in a total volume of $20 \mu \mathrm{l}$ containing $4 \mathrm{ng}$ of genomic DNA, $0.25 \mu \mathrm{M}$ of each primer, $10 \mathrm{mM}$ Tris- $\mathrm{HCl}$ ( $\mathrm{pH} 8.3$ ), $50 \mathrm{mM} \mathrm{KCl}, 3.0$ 
$\mathrm{mM} \mathrm{MgCl}, 200 \mathrm{mM}$ of each dNTP, and 0.25 unit/10 $\mu \mathrm{l}$ Ex Taq DNA polymerase. DNA amplification was performed with a Gene Amp PCR System Model 9600 (Perkin-Elmer) programmed as follows: $95^{\circ} \mathrm{C}$ for $90 \mathrm{~s}, 30$ cycles of $30 \mathrm{~s}$ at $94^{\circ} \mathrm{C}, 30 \mathrm{~s}$ at $55^{\circ} \mathrm{C}$, and $90 \mathrm{~s}$ at $72^{\circ} \mathrm{C}$, followed by $60 \mathrm{~s}$ at $72^{\circ} \mathrm{C}$. The PCR product was separated by electrophoresis in $1.5 \%$ agarose gel and the target fractions were excised from the gel. DNA was recovered from the gel particles and was purified using QIAEX II Gel Extraction (QUIAGEN). The sequence reaction was carried out using a Thermo Sequenase fluorescent labeled primer cycle sequencing kit (Amersham Pharmacia Biotech), the template DNA, and -21M13 (TGTAAAACGACGGCCAGT) / M13Rev (CAGGAAACAGCTATGACC) sequence primer 5'-labeled with Texas Red fluorescent dye (Amersham Pharmacia Biotech). The sequence was analyzed with a Hitachi SQ5500 DNA Sequencer.

Table 2. Primer sequences for amplifying the four cpDNA genes

\begin{tabular}{|c|c|c|c|}
\hline Gene & Zone & Primer & Sequences $\left(5^{\prime} \rightarrow 3^{\prime}\right)$ \\
\hline \multirow[t]{4}{*}{$\operatorname{atp} \mathrm{A}$} & a & FO-021 & (TGTAAAACGACGGCCAGT)GAGGCTTATTTGGGTCGTGT \\
\hline & & FO-124 & (CAGGAAACAGCTATGACC)GAGAACTTGATTTAGCGGCTC \\
\hline & $\mathrm{b}$ & FO-122 & (TGTAAAACGACGGCCAGT)GCTTATCGCCAAATGTCTCTT \\
\hline & & FO-026 & (CAGGAAACAGCTATGACC)ATATGATTTCTTGGAACTGAGG \\
\hline \multirow[t]{2}{*}{ petA } & & FO-055 & $\begin{array}{l}\text { (TGTAAAACGACGGCCAGT)CTTCCCGATACCGTATTT- } \\
\text { GAAGCA }\end{array}$ \\
\hline & & FO-056 & (CAGGAAACAGCTATGACC)TCTGCATCTCCTTGACCAAATCC \\
\hline \multirow[t]{4}{*}{$r b c \mathrm{~L}$} & a & FO-001 & (TGTAAAACGACGGCCAGT)GTCGGATTCAAAGCTGGTGT \\
\hline & & FO-104 & (CAGGAAACAGCTATGACC)TCGCATGTACCCGCAGTAGC \\
\hline & $\mathrm{b}$ & FO-102 & (TGTAAAACGACGGCCAGT)TGAGAATGTGAACTCCCAACC \\
\hline & & FO-006 & (CAGGAAACAGCTATGACC)TCACAAGCAGCAGCTAGTTC \\
\hline \multirow[t]{4}{*}{ rpoA } & a & FO-038 & $\begin{array}{l}\text { (TGTAAAACGACGGCCAGT)GACCTTTTGAGGCAATTATA- } \\
\text { CATCC }\end{array}$ \\
\hline & & FO-040 & (CAGGAAAGAGCTATGACC)CCAAATAACTCTCAAGACGGAA \\
\hline & $\mathrm{b}$ & FO-032 & (TGTAAAACGACGGCCAGT)CGAACAGGCATGAATACAGC \\
\hline & & FO-034 & (CAGGAAACAGCTATGACC)TGGAAGTGTGTTGAATCAAG \\
\hline
\end{tabular}

Remarks: - upper primer was forward primers, below primers was reverse primers - The sequence in parentheses represents the M13/M13Rev universal primer

Raw data of sequences was analyzed using Sequencer 4.7 (Gene Codes Corporation). Both forward and reverse sequences of each samples of each region were assembled automatically using the program. Chromatogram of both sequences was used when incompatibility was found in order to decide the correct sequence of each sample for each region. Finally, all samples for each region were assembled automatically in order to recognize insertion-deletion and base substitution between the samples. 


\section{RESULTS AND DISCUSSION}

\section{A. Intraspecific Variation of the Four Chloroplast Genes}

In order to investigate sequence variations within species, four samples from four separate populations were used in each species (Table 1). Of the four Acacia species, $A$. aulacocarpa was thought to have the largest genetic diversity (Widyatmoko et al., 2010). The samples of this species from New Guinea Island, North Queensland, and South Queensland corresponding to the different subspecies were separated morphologically by Thomson (1994). The length of atpA, pet A, $r b c \mathrm{~L}$, and $r p o \mathrm{~A}$ were $1084 \mathrm{bp}, 561 \mathrm{bp}$, $1309 \mathrm{bp}$, and $782 \mathrm{bp}$, respectively, and no sequence variation was found in the four genes among the four samples. Eventhough McDonald and Maslin (2000) divided $A$. aulacocarpa into 6 species, no sequence variation was found among those species. In the remaining three species, exactly the same results were shown. A low rate of cpDNA mutation has been reported in Acacia acuminata complex in Western Australia (Byrne et al., 2002). the time of divergence between the two main lineages within $A$. acuminata is in the order of 800,000 years ago, in the middle of the Pleistocene. Parfitt and Badeness (1997) and Provan et al. (1999) reported a low cpDNA mutation rate for the genus Pistacia and Pinus torreyana respectively. Restriction site mapping of chloroplast DNA was chosen for phylogenetic analysis because of its ability to provide many information characters, even in comparison to DNA sequence from any particular gene (Jansen et al., 1998)

\section{B. Interspecific Variation Among the Four Acacia species}

In the atp $\mathrm{A}$ and pet $\mathrm{A}$ genes, no sequence variation was found among the four Acacia species. All four species possessed identical sequences. Sequences of the $r b c \mathrm{~L}$ and $r p o \mathrm{~A}$ genes are shown in Figures 1 and 2. Although no length variation among species was observed in either gene, sequence polymorphisms were revealed among these species. Within the four species, $A$. aulacocarpa and $A$. crassicarpa shared an identical sequence, and $A$. auriculiformis and $A$. mangium also showed no sequence variation.

Number of base substitutions and amino acid changes among species are shown in Table 3. In the $r b c \mathrm{~L}$ sequence, six transitions and three transversions were found between the two groups mentioned above. In rpo A, two transitions between the two groups were identified. Five amino acid changes were caused by these substitutions between the groups. The amino acid changes were observed only in the $r b c \mathrm{~L}$ gene.

An inference concerning the genetic relationship among the four Acacia species using RAPD analysis has been reported (Widyatmoko et al., 2010). We indicated that the four species were separated into two clades: $A$. auriculiformis and $A$. mangium were grouped into one clade, and the other clade contained $A$. aulacocarpa and $A$. crassicarpa (Figure 3). In the RAPD study, moreover, genetic variations were observed within and among the species, because a RAPD marker is a more effective means of examining the 
relationship among closely related species. $A$. auriculiformis and $A$. mangium, which were grouped into the same clade, were separated into different respective subclades. In the latter clade, however, which contained $A$. aulacocarpa and $A$. crassicarpa, each species could not clearly form a clade. As a result, $A$. crassicarpa is considered a subspecies of $A$. aulacocarpa. McDonald and Maslin (2000) also mentioned closed relationship between those species. A result similar to this has also been reported by Thomson (1994) whose study was based on morphological observations.

The present study clarified a phylogenetic relationship among the four species. The four Acacia species were classified into two groups. One group contained $A$. auriculiformis and $A$. mangium, and the other consisted of the remaining two species. Within each group, two species had exactly the same sequences in the four cpDNA genes. Between the two groups, 11 substitutions were found in the $r b c \mathrm{~L}$ and $r p o$ A genes. Putative natural hybrids of $A$. aulacocarpa and $A$. auriculiformis have been found (Thomson, 1994). However, our results suggested that $A$. aulacocarpa and $A$. auriculiformis were distantly related. Therefore, natural hybridization between these two species might be further verified using molecular markers.

Interspecific variation among Acacia species have been reported by and Clarke et al. (2000) and Byrne et al. (2002). Byrne et al. (2002) reported a significant association between phylogenetic position of many haplotypes and their geographical distribution. The cpDNA analysis clearly identified $A$. oldfieldii as distinct from the rest of the $A$. acuminata complex. Clarke et al. (2000) reported the phylogenetic relationship between 4 Acacia sub genus Acacia in Caribbean, Africa, South America and North America. A group of Carribean species was found to be ancestral in Acacia subgenus Acacia, and African and South American species were found to relatively derive with respect to North American species.

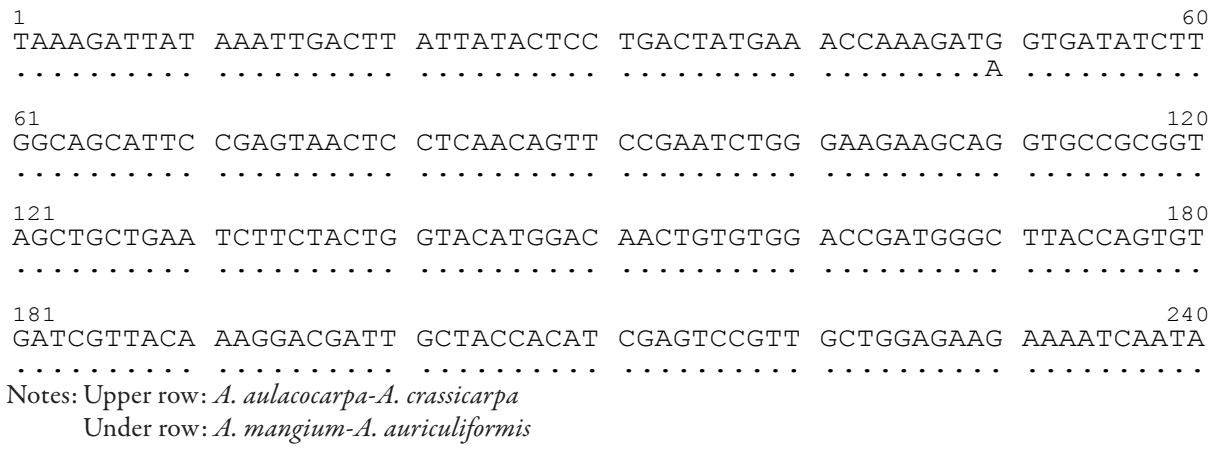

Figure 1. Sequences of $r b c \mathrm{~L}$ of the four Acacia species 
Journal of Forestry Research Vol. 8 No. 1, 2011: 80-90

\begin{tabular}{|c|c|c|c|c|c|}
\hline ATTGCTTAT & GTAGCTTATC & CСТTAC & $\mathrm{AA}$ & A & STI \\
\hline & & $\cdots$ & $\cdots$ & $\cdots$ & $\cdots$ \\
\hline $\begin{array}{l}301 \\
\text { PACTTCGATT }\end{array}$ & GTGGGTAATG & TATTTGGGTT & CAAGGCCCTG & CGCGCTCTAC & $\begin{array}{r}360 \\
\text { GTCTGGAAGA }\end{array}$ \\
\hline$\cdots \cdots \cdots$ & $\cdots \cdots \cdots$ & $\cdots \cdots$ & $\cdots \cdots$ & $\cdots \cdots$ & $\cdots \cdots \cdots$ \\
\hline $\begin{array}{l}61 \\
\text { TTGCGAATC }\end{array}$ & ССтСсттстт & АТТСТААААС & TTTCCAAGGT & CCGCCTCACG & $\begin{array}{r}420 \\
\text { GCATCCAAGT }\end{array}$ \\
\hline$\cdots \cdots \cdots$ & $\cdots \cdots \cdots$ & $\cdots \cdots \cdots$ & $\cdots \cdots \cdots$ & $\cdots \cdots$ & $\cdots \cdots \cdots$ \\
\hline $\begin{array}{l}21 \\
\text { GAGAGAGAT }\end{array}$ & AAATTGAACA & AGTACGGCCG & TCСССТАТTG & GGATGTACTA & $\begin{array}{r}480 \\
\text { TTAAACCAAA }\end{array}$ \\
\hline$\cdots \cdots \cdots$ & $\cdots \cdots \cdots$ & $\cdots \cdots \cdots$ & $\cdots \cdots \cdots$ & $\cdots \cdots \cdots$ & $\cdots \cdots \cdots$ \\
\hline $\begin{array}{l}81 \\
\text { TTGGGGTTA }\end{array}$ & TCCGCGAAGA & АTTACGGTAG & AGCGGTTTAT & GAATGTCTCC & $\begin{array}{r}540 \\
\text { GTGGTGGACT }\end{array}$ \\
\hline$\cdots \cdots \cdots$ & $\cdots \cdots \cdots$ & $\cdots \cdots \cdots$ & $\cdots \cdots \cdots$ & $\cdots \cdots \cdots$ & $\cdots \cdots \cdots$ \\
\hline $\begin{array}{l}41 \\
\text { GATTTTACC }\end{array}$ & AAAGATGATG & AGAATGTGAA & TTCCСAACCA & TTTATGCGTT & $\begin{array}{r}600 \\
\text { GGAGAGACCG }\end{array}$ \\
\hline$\cdots \cdots \cdots$ & $\cdots \cdots \cdots$ & $\cdots \cdots \cdots$ & $\cdots \cdots \cdots$ & $\cdots \cdots \cdots$ & $\cdots \cdots$ \\
\hline $\begin{array}{l}601 \\
\text { TTTСтTAтTT }\end{array}$ & TGTGCCGAAG & СAGTTTTTAA & AGCACAGGCC & GAAACAGGTG & $\begin{array}{r}660 \\
\text { AAATCAAAGG }\end{array}$ \\
\hline$\cdots$ GC $\ldots$ & $\cdots \cdots$ & $\cdots \cdots$ & $\cdots \cdots$ & $\cdots \cdots \cdots$ & $\cdots \cdots{ }_{720}$ \\
\hline САТTAСТTG & АATGCTACTG & CAGGTACATG & CGAAGAAATG & ATCAAAAGAG & CTGTATTTGC \\
\hline 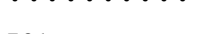 & 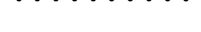 & & & & \\
\hline $\begin{array}{l}721 \\
\text { CCGAGAATTA }\end{array}$ & GGCGTTCCTA & TCGTAATGCA & TGACTACTTA & ACAGGGGGAT & $\begin{array}{r}780 \\
\text { TCACTGCAAA }\end{array}$ \\
\hline$\cdots \cdots G$ & $\cdots A C \ldots$ & $\cdots \cdots$ & $\cdots \cdots$ & $\cdots \cdots$ & $\cdots \cdots$ \\
\hline $\begin{array}{l}781 \\
\text { TCATAGCTTG }\end{array}$ & GСТСАТTATT & GCCGAGATAA & TGGTCTACTT & СТТСАТАТСС & $\begin{array}{r}840 \\
\text { ATCGTGCAAT }\end{array}$ \\
\hline$\cdots \cdots \cdots$ & $\cdots \cdots \cdots$ & $\cdots \cdots$ & $\cdots \cdot$ & $\cdots \cdots \cdots$ & $\cdots \cdots \cdots$ \\
\hline $\begin{array}{l}841 \\
\text { GCATGCAGTT }\end{array}$ & АTCGATAGAC & ACAAGAATCA & TGGTATGCAC & TTTCGTGTAC & $\begin{array}{r}900 \\
\text { TAGCTAAAGC }\end{array}$ \\
\hline$\cdots \cdots \cdots$ & $\cdots \cdots \cdots$ & $\cdots \cdots \cdots$ & $\cdots \cdots \cdots$ & $\cdots \cdots$ & $\cdots \cdots$ \\
\hline $\begin{array}{l}901 \\
\text { GTTACGTATG }\end{array}$ & TCTGGTGGAG & АТСАТАТТСА & CGCTGGTACC & GTAGTAGGTA & AACTTGAAGG \\
\hline$\cdots \cdots \mathrm{T}$ & $\cdots \cdots \cdots$ & $\cdots \cdots \cdots$ & $\cdots \cdots \cdots$ & $\cdots \cdots \cdots$ & $\cdots \cdots \cdots$ \\
\hline $\begin{array}{l}961 \\
\text { TGAAAGAGAA }\end{array}$ & АТСАСТTТАG & GTTTTGTTGT & TTACTACGTA & GATGATTATA & $\begin{array}{r}1020 \\
\text { TTGAGAAAGA }\end{array}$ \\
\hline$\cdots \cdots \cdots$ & $\cdots \cdots$ & $\cdots \cdots \cdots$ & $\cdots \cdots$ & $\cdots \cdots \cdots$ & $\cdots \cdots \cdots$ \\
\hline $\begin{array}{l}1021 \\
\text { TCGAAGCCGC }\end{array}$ & GGTATTTATT & TCACTCAGGA & TTGGGTCTCT & ATGCCGGGTG & $\begin{array}{r}1080 \\
\text { TTCTGCCCTG }\end{array}$ \\
\hline$\cdots \cdots \cdot$ & $\cdots \cdots$ & $\cdots \cdots$ & $\cdots \cdots$ & . A.... & $\cdots \cdots$ \\
\hline $\begin{array}{l}1081 \\
\text { CTTCGGGGGG }\end{array}$ & TATTCACGGT & TTTGGCATAT & GCCTGCTCTT & ACCGAGATCT & $\begin{array}{r}1140 \\
\text { TTGGAGATGA }\end{array}$ \\
\hline$\cdots \cdots$ & $\cdots \cdots$ & $\cdots$ & $\cdots \cdots \cdots$ & $\cdots \cdots \cdots$ & $\cdots \cdots \cdots$ \\
\hline $\begin{array}{l}1141 \\
\text { TTCCGTACTA }\end{array}$ & CAATTCGGGG & GGGGAACTTT & AGGGCACCCT & TGGGGAAATG & $\begin{array}{r}1200 \\
\text { CACCCGGTGC }\end{array}$ \\
\hline$\cdots \cdots$ & $\cdots$ & $\cdots$ & $\cdots \cdots$ & $\cdots \cdots$ & $\cdots \cdots$ \\
\hline $\begin{array}{l}1201 \\
\text { CGTAGCTAAC }\end{array}$ & CGAGTAGCTC & TAGAAGCATG & TGTACAGGCT & CGTAATGAGG & $\begin{array}{r}1260 \\
\text { GACGTGATCT }\end{array}$ \\
\hline$\cdots \cdots \cdots$ & $\cdots \cdots \cdots$ & $\cdots \cdots \cdots$ & $\cdots \cdots \cdots$ & $\cdots \cdots \cdots$ & $\cdots \cdots \cdots$ \\
\hline $\begin{array}{l}1261 \\
\text { TGCTCGTGAG }\end{array}$ & $\begin{array}{c}\text { GGTAATGAAA } \\
. . .\end{array}$ & $\begin{array}{c}\text { ТТАТTCGTCA } \\
\cdots\end{array}$ & $\begin{array}{c}\text { GGCTAGCAAA } \\
\ldots . . .\end{array}$ & $\begin{array}{c}\text { TGGAGTCCT } \\
\ldots \ldots \ldots\end{array}$ & \\
\hline Uppe & $\cdots$ & $a^{\circ}$ & & & \\
\hline
\end{tabular}

Figure 1. (continued) 


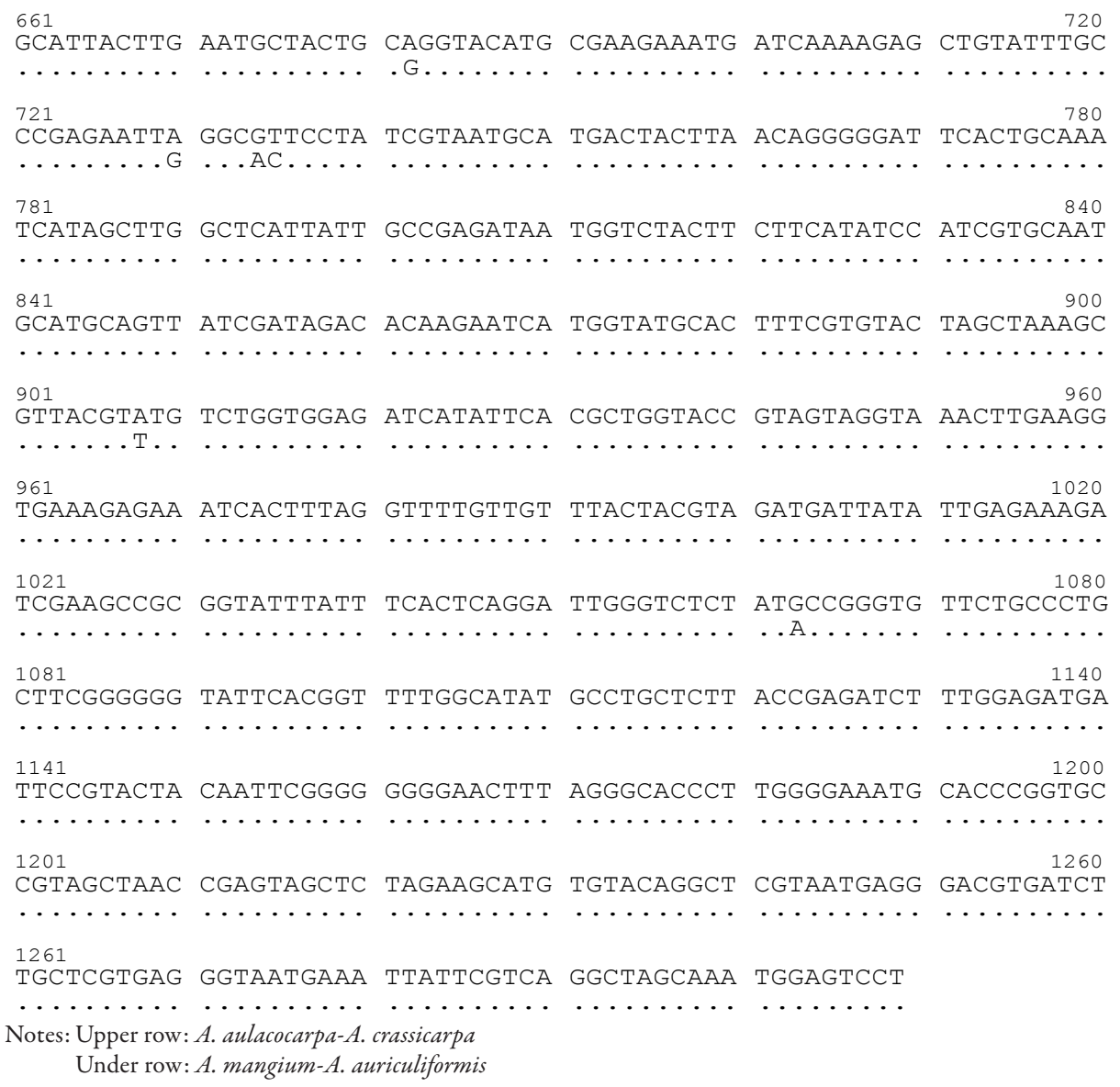

Figure 2. Sequences of rpoA of the four Acacia species

Table 3. Number of substitutions and amino acid changes in the four cpDNA genes of $A$. aulacocarpa- $A$. crassicarpa and $A$. auriculiformis- $A$. mangium

\begin{tabular}{cccccc}
\hline \multirow{2}{*}{ Gene } & Length (bp) & \multicolumn{3}{c}{ Substitution } & \multirow{2}{*}{ Amino acid change } \\
\cline { 3 - 5 } & & Transition & Transversion & Total & 0 \\
\hline atpA & 1084 & 0 & 0 & 0 & 0 \\
petA & 561 & 0 & 0 & 0 & 5 \\
$r b c \mathrm{~L}$ & 1309 & 6 & 3 & 9 & 0 \\
rpo $\mathrm{A}$ & 782 & 2 & 0 & 2 & 5 \\
Total & 3746 & 8 & 3 & 11 & \\
\hline
\end{tabular}




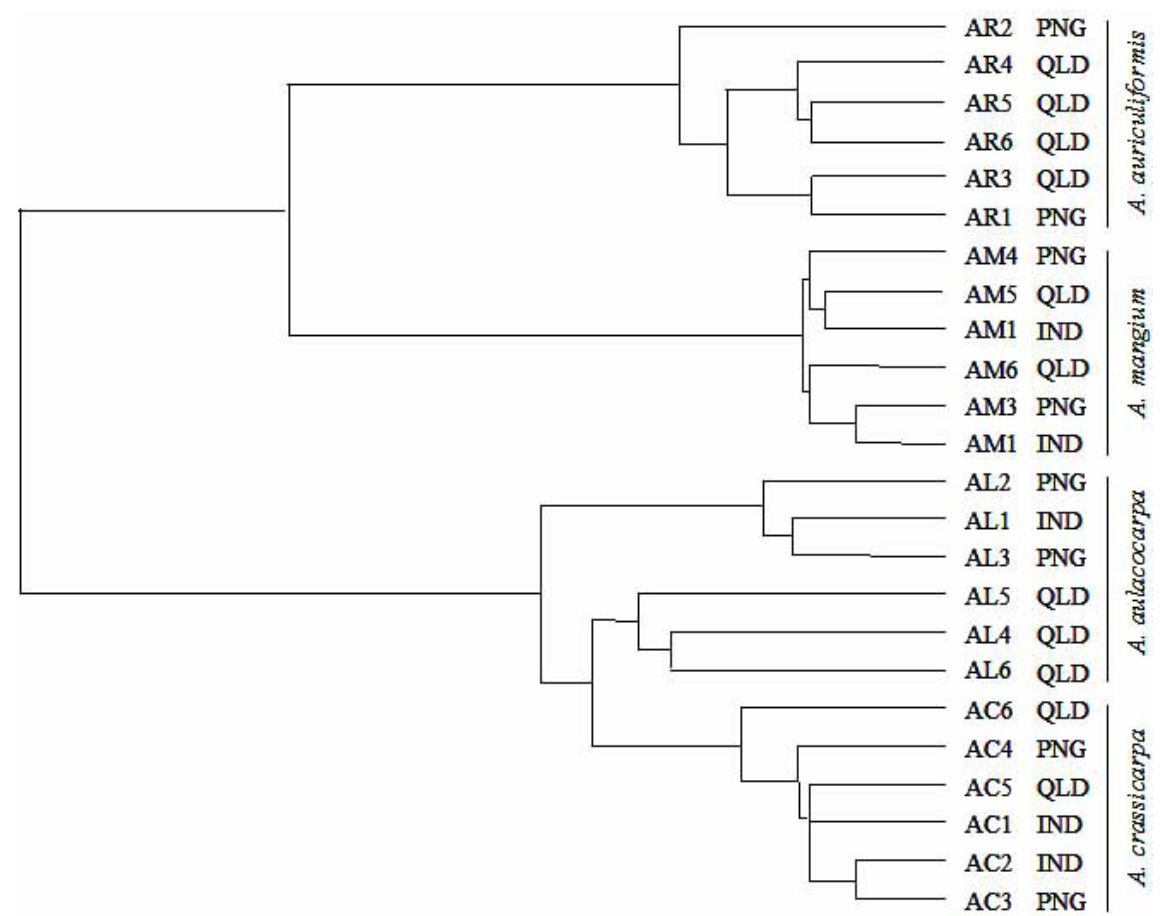

Figure 3. The relationships between four Acacia species (Widyatmoko et al., 2010)

\section{CONCLUSION}

Sequence polymorphisms were revealed among these species for $r b c \mathrm{~L}$ and $r p o \mathrm{~A}$ genes. No sequence variation was found for Acacia aulacocarpa and $A$. crassicarpa, and also for $A$. auriculiformis and $A$. mangium. Both groups were differentiated by 11 bases.

The phylogenic results of this and previous studies may be useful in planning, especially in breeding programs. For $A$. mangium and $A$. auriculiformis, which are extremely closely related, it might be necessary that interspecific hybridization breeding be carried out on a larger scale in the breeding programs. A similar breeding strategy is also worth discussing for $A$. aulacocarpa and $A$. crassicarpa.

\section{REFERENCES}

Amane, M., N. Ouazzani, R. Lumaret and C. Debain 2000. Chloroplast-DNA variation in the wild and cultivated olives (Olea europaea L.) of Morocco. Euphytica 116: 59-64. 
Arisman, H. and E.B. Hardiyanto 2006. Acacia mangium: a historical perspective on its cultivation. In: Potter, K., A. Rimbawanto and C. Beadle (Eds.), Heart Rot and Root Rot in Tropical Acacia Plantations (ACAIR Proceedings No. 124) ACAIR, Canberra, pp. 11-15.

Azuma, T., T. Kajita, J. Yokoyama and H. Ohashi 2000. Phylogenetic relationships of Salix (Salicaceae) based on $r b c \mathrm{~L}$ sequence data. American Journal of Botany 87: $67-75$.

Bohs, L. 2004. A Chloroplast DNA Phylogeny of Solanum Section Lasiocarpa. Systematic Botany 29:177-187.

Boland, D.J., K. Pinyopusarerk, M.W. McDonald, T. Jovanovic and T.H. Booth 1990. The habitat of Acacia auriculiformis and probable factors associated with its distribution. Journal of Tropical Forest Science 3: 159-180.

Brain, P. and B.R. Maslin 1996. A serological investigation of the classification of Acacia subgenus Phyllodineae (Leguminosae: Mimosoideae). Biochemical Systematics and Ecology 24: 379-392.

Brown, G. K., D.J. Murphy, J.T. Miller and P.Y.Ladiges 2008. Acacia s.s. and its Relationship Among Tropical Legumes, Tribe Ingeae (Leguminosae: Mimosoideae). Systematic Botany 33:739-751.

Byrne, M., B. MacDonald and D. Coates 2002. Phylogeographical patterns in chloroplast DNA variation within the Acacia acuminata (Leguminosae: Mimosoideae) complex in Western Australia. Journal of Evolutionary Biology 15 : 576-587.

Byrne, M., G. Tischler, B. Macdonald, D.J. Coates and J. McComb, J. 2001. Phylogenetic relationships between two rare acacias and their common, widespread relatives in south-western Australia. Conservation Genetics 2: 157-166.

Chase, M.W., C.M. Morton and J.A. Kallunki 1999. Phylogenetic relationship of Rutaceae: a cladistic analysis of the subfamilies using evidence from rbcL and atpB sequence variation. American Journal of Botany. 86: 1191-1199.

Chen, Z-D., S.R. Manchester and H-Y. Sun 1999. Phylogeny and evolution of the Betulaceae as inferred from DNA sequences, morphology and paleobotany. American Journal of Botany. 86: 1168-1181.

Clarke, H.D., S.R. Downie, and D.S. Seigler 2000. Implications of chloroplast DNA restriction site variation for systematics of Acacia (Fabaceae: Mimosoideae). Systemactic Botany 25: 618-632.

Fujii, N., K. Ueda, Y. Watano and T. Shimizu 1999. Further analysis of intraspecific sequence variation of chloroplast DNA in Primula cuneifolia Ledeb. (Primulaceae): implication for biogrography of Japanese Alpine flora. Journal of Plant Research 112: 87-95. 
Hamrick, J. L., M.J.W. Godr, and S.L.S. Broyles 1992. Factors influencing levels of genetic diversity in woody plant Species. New Forests 6: 95-124.

Jansen, R. K., J.L. Wee and D. Millie 1998. Comparative utility of chloroplast DNA restriction site and DNA sequence data for phylogenetic studies in plants. Pp. 87 - 100 in Molecular systematic of Plants II: DNA sequencing, eds. D. E. Soltis, P. S. Soltis and J. J. Doyle. Norwell, Massachusetts: Kluwer Academic Publicher.

McDonald, M. W. and B.R. Maslin 2000. Taxonomy revision of the Salwood: Acacia aulacocarpa Cunn. Ex Benth. And its allies (Leguminosae: Mimosoideae: secion Juliflorae). Australian Systematic Botany 13:21-78.

Moran, G. F., O. Muona and J.C. Bell 1989. Breeding systems and genetic diversity in Acacia auriculiformis and A. crassicarpa. Biotropica 21:250-256.

Parfitt D. E. and M.L. Badeness 1997. Phylogeny of the genus Pistacia as determined from analysis of the chloroplast genome. Proceeding of the National Academy of Science. 94: 7987-7992.

Pettigrew, C. J. and L. Watson 1975. On the classification of Australian Acacias. Australian Journal of Botany 23: 833-847.

Potter, K., A. Rimbawanto, and C. Beadle 2006. Preface. In: K. Potter, A. Rimbawanto, C. Beadle (Eds.), Heart Rot and Root Rot in Tropical Acacia Plantations ACIAR Proceedings No. 124, Canberra, p.7.

Provan, J., N. Soranzo, N.J. Wilson, D.B. Goldstein and W. Powell, W. 1999. A low mutation rate for chloroplast microsatellites. Genetics 153: 943-947.

Thomson, L.A.J. 1994. Acacia aulacocarpa, $A$. cincinnata, $A$. crassicarpa and $A$. wetarensis: an annotated bibliography. Division of Forestry, Australian Tree Seed Centre, Canberra. $131 \mathrm{p}$.

Widyatmoko, A.Y.P.B.C., A. Watanabe, A. Rimbawanto and S. Shiraishi 2010. Genetic variations and relationship in four species of section Juliflorae, genus Acacia using DNA molecular markers. Journal of Forestry Research 7 (2): 125-143.

Zimmer, E.A., E.H. Roalson, L.E. Skog, J.K. Boggan and A. Idnurm 2002. Phylogenetic relationships in the Gesnerioideae (Gesneriaceae) based on nrDNA ITS and cpDNA trn L-F and trnE-T spacer region sequences. American Journal of Botany 89: 296-311. 